\title{
Rising English Students' Motivation in Online Learning Platform: Telegram Apps Support
}

\author{
Rasyidah Nur Aisyah ${ }^{1}$, Dewi Masitho Istiqomah ${ }^{1} \&$ Muhammad Muchlisin $^{2}$ \\ ${ }^{1}$ PGRI Wiranegara University, Pasuruan, Indonesia \\ ${ }^{2}$ State Vocational High School 4 Malang, East Java, Indonesia \\ ocicyah@gmail.com
}

\section{ARTICLE HISTORY}

Received : 2021-04-10

Revised : 2021-06-21

Accepted : 2021-07-26

\section{KEYWORDS}

Telegram App

Telegram Bot

E-learning

Students'Motivation

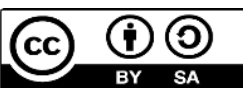

\begin{abstract}
This study believes that it needs an effort that encourages students to carry out learning activities to achieve predetermined goals and motivation to determine students' success in the teaching-learning process. The objective of this study is to know the students' motivation in learning after using e-learning materials using the Telegram app, i.e., telegram bot. This descriptive quantitative research used a closed questionnaire with 11 modified questions, and it was delivered to 46 respondents. Based on analysis of students' learning motivation before using the telegram bot it was highlighted into a good category $80.56 \%$ ]. This study also manage to reveal three aspects that construct this presents study, namely interests, concerns, and needs. The analysis manage to record that the interesting aspect received $78.19 \%$, the concern aspect received $82.18 \%$, and the need aspect received $81.56 \%$. Thus, and the average score of students' learning motivation was $80.56 \%$. After using the telegram bot, the details of the recapitulation of the motivation questionnaire are as follows, aspects of interest get $84.17 \%$, aspects of attention get $87.23 \%$, aspects of needs get $86.70 \%$, and the average score of student learning motivation is $85.98 \%$. Thus, it can be concluded that the use of telegram bot as e-learning materials can increase student motivation.
\end{abstract}

\section{Introduction}

There were a lot of studies about students' motivation in teaching English as Foreign Language (TEFL) field (Alimyar, 2020; Anwar \& Wardhono, 2019; Aspuri et al., 2019; Cahyono \& Rahayu, 2020; Caldwell, 2018; Genç \& Aydin, 2010; Huang et al., 2016), and some of them are about EFL Students' motivation in learning English by using ICT, for instance, podcast (Indahsari, 2020), mobile learning (Abu Laban, 2017; Winarto \& Hardyanto, 2019). However, research on the role of motivation in EFL (English as a foreign language) by using Telegram as the teaching media is a rare undertaking. Therefore, researchers need to research this topic. Especially with the government's policy that during the covid-19 pandemic, the teaching and learning process must be carried out online. Of course, it greatly affects student learning motivation, usually carried out face-to-face in class but immediately changes. From the current phenomenon, further research is needed on student learning motivation, which generally occurs in class face-to-face but simultaneously throughout Indonesia, which must be carried out online at home. One of the media used in this online class is the Telegram apps, which is only known for many people as limited to social media, Still, there are many features provided by the Telegram Application that are very useful in online-based learning (Aisyah et al., 2021).

Dorney (2008) mentioned that motivation is a key to a successful process. Teaching and learning can be interpreted as the effort that can encourage someone to do something or the locomotion of the subject to do an action in a destination. Learning motivation is promoting psychological conditions for someone to know so that results in learning generally increases if learning motivation increases. The essence of learning motivation is the impulse that comes from inside and outside the student's learning to make changes in behavior and enthusiasm or desire to learn more passionately again. The motivation from within the individual is called intrinsic motivation, while the motivation comes from outside the individual, as desire gets good grades, promising career, and so-called extrinsic motivation (Alshenqeeti, 2018).

Meanwhile, there are two types of orientation according to Gardner (1985) in Dörnyei (2008), namely integrative and instrumental. Integrative orientation refers to the desire to learn and become part of the cultural community, the desire to be like an expert in other language communities, and a 
relationship with the community. In contrast, the instrumental orientation emphasizes the goal to get social recognition or economic benefits through knowledge of the foreign language, like succeeding in exams, meeting the requirements specific, career, travel to abroad, and others. Apart from motivation and orientation, another factor that is no less important can affect students' learning achievement, especially learning languages, is the students' attitude of the against the language that is learning. The attitude of the language is the attitude of the user language against diversity own language and language other people. Language attitude is position mentality or feelings towards language itself or others Kridalaksana, 2013). Fasold (1984) in (Chalak \& Kassaian, 2010) generally mentions one's attitude towards a language is reflected in his attitude towards speakers native to the language. Attitude language can be changeable, positive, harmful, or neutral depending on the experience obtained.

Motivational components that are specific to learning situation based on Dornyei (2008) it appears helpful to separate three sets of motivational components (motives and motivational conditions): 1) course-specific motivational components concerning the syllabus, the teaching materials, the teaching method, and the learning tasks; 2) teacher-specific motivational components concerning the teacher's personality, teaching style, feedback, and relationship with the students; and 3) group-specific motivational components concerning the dynamics of the learning group. Keller's motivational system postulates four major motivational factors to describe L2 classroom motivation: interest, concern, and need. This framework appears to be particularly useful in describing course-specific motivation.

Online learning allows students to have the flexibility of learning time so they can study anytime and anywhere. In addition, students can interact with lecturers using several applications such as eclassroom, video conference, telephone or live chat, zoom, or via WhatsApp group (Dhull \& Sakshi, 2017). This learning activity is an educational innovation to answer the challenge of the availability of varied learning resources. The success of a model or learning media depends on the characteristics of the students; this is expressed by (Nakayama et al., 2014) Nakayama et al. (2014) that from all the literature indicates that not all students will be successful in online learning, this is due to differences in learning environment factors and student characteristics. One of the successes in learning is related to the students' motivation (Schunk et al., 2014). According to Brophy (2010) that motivation is a theoretical construction to explain the initiation, direction, intensity, persistence, and quality of behavior, especially goal-directed behavior. Motivation provides impetus for purposeful action in the desired direction both physically and mentally, so activity becomes a very important part of motivation (Lee \& Martin, 2017). Motivation can influence what we learn, how we learn, and when we choose to learn (Schunk \& Usher, 2012). Motivated students are likely to do challenging activities, be active, enjoy the process of learning activities and show increased learning outcomes, perseverance and creativity (Samir Abou El-Seoud et al., 2014). In addition, designing a learning environment that motivates students will attract students' attention (Keller, 2010). According to Selvi (2010) explained(2010) explains that online learning is often required to be more motivated because the learning environment usually depends on motivation and related characteristics of curiosity and self-regulation to involve in the learning process. Technology itself is inherently motivating because it provides several qualities recognized as necessary in cultivating intrinsic motivation, namely challenge, curiosity, novelty, and fantasy (Lepper et al., 2005). It is considered an essential factor for successful learning, including in online learning environments, so it is necessary to reconsider learning motivation in learning environments that use technology (Harandi, 2015). For this reason, researchers must examine how student motivation on online learning, especially the learning activities is carried out during the Covid-19 Pandemic. Conducting this research with the aim provides an accurate description of how student learning motivation is in online edcation during the Covid-19 Pandemic.It becomes an evaluation material in creating effective online learning in Covid-19 Pandemic. Besides this research can also be used as study material other researchers related to student motivation in online learning during the Covid-19 Pandemic.

Therefore, this study seeks to analyzed students' motivation based on their interest, concern, and language learning situation through teaching media by using a telegram bot. The novelty in this study is for the teacher educator, after they can measure their students' learning motivation, it is hoped that lecturers will be able to improve their teaching styles to increase students' motivation in learning. Nevertheless, the main question raised in this present study is "How are the students' motivation in the teaching and learning process by using telegram bot?"

\section{Literature Review}

\subsection{Definition of Motivation}

According to Usher et al. (2012), motivation is an energy change in a person marked by the emergence of feelings and is preceded by a response to a goal. Motivation is one of the factors that determine students get success in the teaching-learning process. Students who have high motivation always try continuously to achieve their goals. Conversely, students who have low motivation will not care about their learning progress. Based on this description, it can be concluded that motivation is an effort that encourages students to carry out learning activities to achieve predetermined goals. It is supported by the opinion of Seifert (2004) that 
motivation is an energy that drives, guides, and strengthens behavior. From this understanding, motivation contains three essential elements according to Usher et al. (2012), namely:

a) Motivation initiates a change in energy in each individual,

b) Motivation is characterized by the emergence of feeling someone's affection.

c) Motivation will be stimulated for the purpose

Williams and Williams (2011) explain that there are three main components in motivation, namely: 1) need, 2) encouragement, and 3) goals. Needs occur when the individual feels a balance between what he has and what he hopes for. For example, students need good results: then these students change the way they learn. Encouragement is the mental strength to carry out activities to meet expectations or achieve goals.

Furthermore, goals are what an individual wants to achieve.-these goals direct behavior in terms of learning behavior. (Vero \& Puka, 2017) stated that motivated learning actions can be said to be learning activities carried out by students, driven by the needs they feel so that these actions lead to the desired direction.

Motivation and learning are two things that influence each other. Students will study actively if they have the motivation to learn. Good and Brophy (2011) state that learning is a process of interaction by a person in obtaining something new in the form of behavior change resulting from a learning experience. Learning motivation indicators according to (Riswanto \& Aryani, 2017), are classified as follows: 1) desire and desire for results, 2) drive and need in learning, 3) hopes and aspirations for the future, 4) appreciation in learning, 5) exciting activities in learning, and 6) a conducive learning environment, allowing students to learn well.

\subsection{Function of Motivation}

According to Usher et al. (2012), there are three motivational functions of motivation as follows:

a) Encourage behavior or action. Without motivation, there will be no action such as learning.

b) Motivation functions as a guide, which means directing an act of achieving the desired goal.

c) Motivation as a driving force. It will determine whether a job is fast or slow.

Seifert (2004) suggests several elements that affect learning motivation, namely:

\section{a. Ambition}

The ideals will strengthen the learning motivation of students, both intrinsic and extrinsic. Because the achievement of standards will bring about selfactualization

\section{b. The ability of students}

The desires of a child need to be accompanied by abilities or abilities in achieving them. The ability will strengthen children's motivation to carry out developmental tasks.

\section{c. The condition of students}

The condition of students includes physical and spiritual conditions that can affect learning motivation. A student who is sick will interfere with learning attention. Conversely, a healthy student will quickly focus on learning.

\section{d. Environmental conditions}

The environment of students can be in the form of conditions of residence, association, and community life. The condition of a healthy school environment and a comfortable environment will increase the enthusiasm of students' motivation to learn.

\subsection{Telegram Application}

Telegram is a cloud-based social media application, meaning it can easily move conversations between smartphones, the web, and the desktop. Telegram apps can share pictures and videos, transfer documents and send current locations easily. Telegram has various features like those used as social media. The primary component of the telegram is almost the same as most other social media applications that can be used as conversation communication (chat), there are group chat, and sending files without size restrictions. It is the superior from other social media, which have size restrictions for sending.

The telegram application can be downloaded via google-play-store for Android-based smartphones or the app store for IOS-based smartphones. It can be run on personal computers or notebooks via http://desktop.telegram.org/

This application requires an internet network to use. Here are the steps that users must take to install and use the telegram application.

1) click start to start the telegram application

2) Enter the phone number to register

3) Enter the verification number sent by telegram to the registered phone number

4) Search for telegram bot with the keyword id @ICTforELT_bot in the search menu

5) Then click start, and the teaching materials are ready for use.

\subsection{Telegram Bot}

Telegram's excellent feature is the bot telegram. Bots are programs developed by bot developers that do 
certain jobs automatically. A bot can be said to be an automatic program/command operated by software created by a bot developer by this understanding. A Telegram bot is an application hosted on a server that uses Telegram bot API to connect to Telegram Messenger clients (Zaff. H, 2017). If we want to create a bot, it will be guided by the BotFather, and we just need to follow a few simple steps. Once we've created a bot and received our authorization token, the BotFather will guide us on what to do next (Wardhono \& Spanos, 2018). A telegram bot is like a virtual robot programmed with instructions and answers or interacting with the user. We create a bot to make the lesson more interactive because the students can interact with the bot that is like a teacher robot. The students simply click the material menu that they need and read the material explanation or watch the learning videos already embedded in it. Moreover, Students also can take the quiz through this bot. The format of this quiz is a multiple-choice, simple question, and multiple answer question (Muchlisin, 2019).

\subsection{Internet as a Teaching Media}

Learning that uses interactive media such as elearning cannot be separated from the internet network. Internet network is also defined as a computer network that connects computers worldwide so that all information can be communicated around the world instantly and globally. The internet also provides various direct communication access services, namely email and chat. Along with internet development, many activities have been carried out using the internet network, such as e-banking, e-government, e-learning, and others. E-learning is a form of application of information technology in education in virtual classes. E-learning is learning that utilizes internet networks.

The use of the internet as a teaching media makes students learn independently. Rusman (2013) states that students can access online libraries, museums, databases and get primary sources on various authentic materials. For educators and students, the internet is a source of knowledge that is always up to date, compared to books sold on the market. The internet as a learning mediais expected to improve the interactive communication process between educators and students.

The development of internet technology has been used by various experts for various purposes including for the world of education. The advancement of internet technology has conducted many experiments to develop software to support efforts to improve the quality of education. Sa'ud (2012) states that the internet as a learning medium has unique characteristics: 1 . as an interpersonal medium and mass media, 2. It has an interactive nature, and 3. It allows synchronous and asynchronous communication to occur, allowing the third type of communication dialogue which is a prerequisite for implementing the teaching and learning process.

\section{Method}

\subsection{Research Design}

In this research, the researcher conducted descriptive quantitative research. The researcher chose quantitative research because it presents numerical data, which is more valid than just narration. Here, the researcher described the students' motivation in learning English by using the Telegram bot. (Creswell, 2009) stated that quantitative research is typically acquired from assessment, students' scores, questionnaires, and interviews. While this type of research uses a survey. According to (Pinsonneault \& Kraemer, 1993) that survey research is seen as a method to describe quantitatively specific aspects of a particular population so that data collection is carried out to a group of people whose results can be generalized back into a particular population.In comparison, this type of research uses a survey. According to (Pinsonneault \& Kraemer, 1993), survey research is seen as a method to describe quantitatively specific aspects of a specific population. Data collection is carried out to a group of people whose results can be generalized back into a particular population.

\subsection{Respondents}

The respondents of this study were all English students of the Pedagogy and Psychology Faculty at PGRI Wiranegara University Pasuruan in 2019/2020. The latterjoined ICT for ELT course in the odd semester. The respondents of this research consisted of approximately 47 students.

\subsection{The Technique of Data Collection}

The type of data in this research is quantitative data. Data was obtained through quantitative data, including filling out a questionnaire. The questionnaire used in this study was a motivation questionnaire. Motivation questionnaires are filled in by students who aim to measure the motivation of students. Survey research is very suitable for revealing how student motivation is in online learning during this Covid-19 pandemic.

\subsection{Instruments}

The instrument that used in this study was a questionnaire. The questionnaire used is closed, namely, a questionnaire that has provided answer choices. The respondent only needs to choose the appropriate answer by giving five checks $(\sqrt{ })$ in the answer column that has been provided. The motivational questionnaire instrument is a motivation questionnaire sheet before and after using e-learningbased learning teaching materials utilizing the telegram application. This motivation questionnaire is aimed at students to measure the level of learning motivation of students. 


\subsection{The Technique of Data Analysis}

The data analysis technique in this research is quantitative data analysis techniques. Quantitative data analysis techniques are descriptive statistical data used to process numerical data. The formula for processing quantitative data on learning motivation, according to (Shavelson et al., 2003), is as follows:

$\mathrm{P}=\frac{\sum \mathrm{X}}{\sum \mathrm{X}_{1}} \times 100 \%$

Noted:

$\mathrm{P} \quad$ : percentage sought

$\sum \mathrm{X} \quad$ : number of answers to scores by respondents $\sum \mathrm{X}_{1}$ : the maximum number of answers in this aspect of research by respondents

$100 \%$ : constant

\section{Results}

\subsection{Early 'students motivation in learning English by using Telegram Bot}

Researchers distribute this questionnaire to find out how much motivation learners learn when teaching and learning process. The aspects measured include interests, concerns, and needs. The format of the student motivation questionnaire can be seen in the attachment. The results of students' learning motivation questionnaire before using e-e-learning teaching materials can be seen in the following table.

Table 1. Data of Questionnaire Results of Students' Learning Motivation Before using Telegram Bot

\begin{tabular}{llllll}
\hline No. & Aspects that scored & Scores of students' answers & Max Score & $\begin{array}{l}\text { Percentage } \\
(\%)\end{array}$ & Note \\
\hline 1 & Interests & 588 & 752 & 78.19 & Good \\
2 & Concerns & 618 & 752 & 82.18 & Good \\
3 & Needs & 460 & 564 & 81.56 & Good \\
\hline & Total & 1666 & 2068 & 80.56 & Good \\
\hline
\end{tabular}

Based on the questionnaire assessment analysis of students' learning motivation before using the telegram bot, it can be seen that students' learning motivation is a good category. This assessment is based on three aspects, namely interests, concerns, and needs. The interesting element received $78.19 \%$, the concern aspect received $82.18 \%$, the need aspect received $81.56 \%$. Thus, and the average score of students' learning motivation was $80.56 \%$.

\subsection{The Final Students' Motivation in Learning English by using Telegram Bot}

After using e-learning teaching materials using the telegram bot, the researchers distributed a motivation questionnaire after the teaching and learning process.
This is done to determine the extent to which the use of this teaching material can increase the final motivation of students. Therefore, based on the results of the questionnaire assessment analysis of students' learning motivation after using telegram bot in the teaching-learning process, it can be seen that the learning motivation of students is a very good category. The details of the results of the recapitulation of the motivation questionnaire are as follows, namely aspects of interest get $84.17 \%$, aspects of attention get $87.23 \%$, aspects of needs get $86.70 \%$, and the average score of student learning motivation is $85.98 \%$.

Table 2. Data of questionnaire results of students' learning motivation after using Telegram bot

\begin{tabular}{llllll}
\hline No. & Aspects that scored & Scores of students' answers & Max Score & $\begin{array}{l}\text { Percentage } \\
(\%)\end{array}$ & Note \\
\hline 1 & Interests & 633 & 752 & 84.17 & Good \\
2 & Concerns & 656 & 752 & 87.23 & Very Good \\
3 & Needs & 489 & 564 & 86.70 & Very Good \\
\hline
\end{tabular}

\section{Discussion}

Students feel helped by comments and corrections from the lecturer and other students in the teaching and learning process while using Telegram. Some correction from other students is considered important, but students still expect input from the lecturer. For this reason, lecturers are expected to guide students on an ongoing basis by providing input, comments, and corrections, either directly or indirectly. Lecturers can also provide direct corrections which allow students to study the input and corrections given by the lecturer repeatedly, wherever and whenever, without having to meet directly with the lecturer. 
In line with that, online discussions can provide opportunities for students to actively participate in discussions wherever and whenever. Students are motivated and participate actively in online discussions (Nielsen, 2013) and can do it on campus, at home, and whenever they want (Kusuma \& Adnyani, 2016). Besides, online discussions also provide opportunities for students to become tutors for other students (AlShaer, 2013). Students can post their writing in the telegram group and provide comments or comments by other students. In addition to improving English language skills in learning, lecturers can also provide students to practice English not only in class but also outside the classroom.

The notification feature on the Telegram group provides the latest notifications about learning. In addition, the telegram bot menu also offers many learning videos. Students can search according to their needs, not only material in the form of videos but also in ppt files, pdf files, or image files. Based on that, Telegram becomes something interesting because learning materials for one semester are already available in it.

The online teaching and learning process has a very positive impact on the learning implementation process. Students can discuss with lecturers and colleagues various materials that have not been understood virtually. Using social media in online learning, students can repeat the subject matter and are motivated to discuss with friends and lecturers. Many of them get new information and share it with friends or share the information through discussion and question and answer.

The advantages of e-learning using telegram application are: 1) Educators and students can use elearning anytime and anywhere, without space and time limitations, 2) e-learning is easy to operate by beginners, the use of teaching materials is very simple, 3) The list of bots is packaged thoroughly, so that users have no difficulty operating the teaching materials, 4) The material presented is arranged systematically, according to the basic competencies to be achieved by students, 5) students can learn independently, and 6) teaching materials can be used repeatedly.

Fun learning activities certainly increase enthusiasm for the lesson. Students will dig up information if they feel happy with something. Related to this teaching and learning, the material presented in an interesting way will certainly be easy for students to remember. It is known that students who have understood the concepts in a material become easier to develop their analysis. This is what happened in this study, with the online learning model being able to increase student interest and creativity in learning, which also improved student learning outcomes in education.

\section{Conclusion}

Based on the questionnaire assessment analysis of students' learning motivation before using the telegram bot, it can be seen that students' learning motivation is a good category. This assessment is based on three aspects, namely interests, concerns, and needs. The interesting aspect received $78.19 \%$, the concern aspect received $82.18 \%$, and the need aspect received $81.56 \%$. Thus, and the average score of students' learning motivation was $80.56 \%$. Researchers were tried to increase students' learning motivation by teaching using e-learning in a telegram bot. After the teaching and learning process using the telegram bot, there were increases in students' learning motivation. The three aspects that are considered to have increased. The details of the results of the recapitulation of the motivation questionnaire are as follows, namely aspects of interest get $84.17 \%$, aspects of attention get $87.23 \%$, aspects of needs get $86.70 \%$, and the average score of student learning motivation is $85.98 \%$

Thus the use of telegram bot as a teaching media can increase students' motivation to learn, there is an increase of $5.42 \%$. Therefore it can be concluded that the use of telegram bot as e-learning materials can increase student motivation. Online Learning by using a Telegram-based is the right solution during the current COVID-19 pandemic. Using Telegram provides opportunities for students who have different characteristics to become the primary goal of online learning be independent, sustainable, and developing learning occurs, makinglearning more effective, efficient, and enjoyable. This learning model still makes lecturers facilitators in student development, not as the main center of learning. Lecturers guide students to explore such extensive information through the internet jointly.

\section{References}

Abu Laban, M. M. (2017). The Effectiveness of Using Mobile Learning in Developing Eleventh Graders ' English Grammar Learning and Motivation for English. https://iugspace.iugaza.edu.ps/handle/20.500.123 $58 / 18819$

Aisyah, R. N., Istiqomah, D. M., \& Muchlisin, M. (2021). Developing E-learning Module by Using Telegram Bot on ICT for ELT Course. Proceedings of the 5th International Conference on Arts Language and Culture (ICALC 2020), 534(534), https://doi.org/10.2991/assehr.k.210226.054

Al-Shaer, I. (2013). Effects of a blended learning module on EFL students' attitudes in an introductory reading course in Al-Quds open university setting. International Journal of Language Learning and Applied Linguistics World, 3(4), 224-242. 
Alimyar, Z. (2020). Attitudes and Motivation of Afghan Students toward Learning English. Journal of English Education, 5(1), 19-33. https://doi.org/10.31327/jee.v5i1.1172

Alshenqeeti, H. (2018). Motivation and Foreign Language Learning: Exploring the Rise of Motivation Strategies in the EFL Classroom. International Journal of Applied Linguistics and $\begin{array}{lll}\text { English } \quad \text { Literature, } & 7(7), & 1 .\end{array}$ https://doi.org/10.7575/aiac.ijalel.v.7n.7p.1

Anwar, K., \& Wardhono, A. (2019). Students' perception of learning experience and achievement motivation: Prototyping English for academic purposes (EAP). International Journal of Instruction, 12(3), 271-288. https://doi.org/10.29333/iji.2019.12317a

Aspuri, N., Samad, I. A., Fitriani, S. S., \& Abdul Samad, N. M. (2019). the Role of Instrumental Motivation Among Efl Students in Language Learning Process. Journal of English Education, 4(1), 48-53. https://doi.org/10.31327/jee.v4i1.892

Cahyono, B. Y., \& Rahayu, T. (2020). Efl students' motivation in writing, writing proficiency, and gender. Teflin Journal, 31(2), 162-180. https://doi.org/10.15639/teflinjournal.v31i2/162180

Caldwell, M. (2018). Japanese university students' perceptions on the use of ICT and mobile-learning in an EFL setting. Call-Ej, 19(2), 188-216.

Chalak, A., \& Kassaian, Z. (2010). Motivation and attitudes of Iranian undergraduate EFL students towards learning english. GEMA Online Journal of Language Studies, 10(2), 37-56.

Creswell, J. W. (2009). Reseacrh Design: Qualitative, Quantitative, and Mixed Methods Approaches Third Edition. In Sage. Sage. https://doi.org/10.2307/1523157

Dorney, Z. (2008). Motivation Foreign Language Motivating in Classroom the. The Modern Language Journal, 78(3), 273-284.

Genç, G. (Inonu U. (2010). Students' motivation towards computer use in EFL learning. Estudiopresentado En El International, 2009, 2009-2011.

http://ezproxy.lib.ucf.edu/login?URL=http://searc h.ebscohost.com/login.aspx?direct=true $\& \mathrm{db}=$ eric $\& \mathrm{AN}=\mathrm{ED} 511166 \&$ site $=$ ehost -

live\%5Cnhttp://w3.balikesir.edu.tr/ saydin/index _dosyalar/ietc2010-3-Aydin-Genc.pdf

Huang, C. S. J., Yang, S. J. H., Chiang, T. H. C., \& Su, A. Y.S. (2016). Effects of situated mobile learning approach on learning motivation and performance of EFL students. Educational Technology and Society, 19(1), 263-276.
Indahsari, D. (2020). Using podcast for EFL students in language learning. JEES (Journal of English Educators Society), 5(2), 103-108. https://doi.org/10.21070/jees.v5i2.767

Kusuma, I. P. I., \& Adnyani, L. D. S. (2016). Motivasi dan Sikap Bahasa Mahasiswa Jurusan Pendidikan Bahasa Inggris Undiksha. JPI (Jurnal Pendidikan Indonesia), 5(1), 12-26.

Muchlisin, M. (2019). The Power of Telegram as a Digital English Learning Media Abstract. RETCO 9 National Seminar UNIROW Tuban, December 14-15, 12-19.

Nielsen, B. (2013). Students' perceptions and learning outcomes of online writing using discussion boards. The JALT CALL Journal, 9(2), 131-147. https://doi.org/10.29140/jaltcall.v9n2.152

Riswanto, A., \& Aryani, S. (2017). Learning motivation and student achievement: description analysis and relationships both. The International Journal of Counseling and Education, 2(1), 42-47. https://doi.org/10.23916/002017026010

Seifert, T. L. (2004). Understanding student motivation. Educational Research, 46(2), 137-149. https://doi.org/10.1080/0013188042000222421

Shavelson, R., Ruiz-Primo, M. A., Li, M., \& Ayala, C. C. (2003). Evaluating New Approaches to Assessing Learning (CSE Report 604). National Center for Research on Evaluation, Standards, and Student Testing (CRESST), 1522(310).

Usher, A., Kober, N., Jennings, J., \& Rentner, D. S. (2012). Student Motivation - An Overlooked Piece of School Reform. In The George Washington University.

Vero, E., \& Puka, E. (2017). The Importance of Motivation in an Educational Environment. Formazione \& Insegnamento, XV(1), 57-66. http://www.lulu.com/shop/gazala-bhoje/theimportance-of-motivation-in-an-educationalenvironment/paperback/product-22168435.html

Wardhono, A., \& Spanos, S. (2018). Assessing English Speaking and Listening Skilss with the Mobile Application Telegram. Indonesian EFL Journal: Journal of ELT, Linguistics, and Literature, 4(2), 147-174. https://doi.org/10.4324/9781315175522-43

Williams, K., \& Williams, C. (2011). Five key ingredients for improving student motivation. Res High Educ J, 12, 1-23.

Winarto, A., \& Hardyanto, W. (2019). Telegram Development in Dokeos-Based E-Learning As a Learning Media to Improve Students' Motivation in Learning Physics. Physics Communication, O(0), 78-85. https://doi.org/10.15294/physcomm.v0i0.20628 